\title{
PROGRAM CORPORATE SOCIAL RESPONSIBILITY PT. ANGKASA PURA II (PERSERO) DALAM MEMBANGUN CITRA PERUSAHAAN (STUDI DESKRIPTIF KUALITATIF PADA PROGRAM KEPEDULIAN SOSIAL 2019)
}

\author{
Lina Wati, S.Sos.I.,M.Ikom \\ Ananda Suci Faradita \\ linawati@unis.ac.id \\ Prodi S1 Ilmu Komunikasi, Fakultas Ilmu Sosial dan Ilmu Politik \\ Universitas Islam Syekh Yusuf Tangerang
}

\begin{abstract}
This study determine the corporate social responsibility program of PT Angkasa Pura II (Persero) in improving the company's image. This research uses descriptive qualitative method, which describes the reality being studied. Data collection techniques using in-depth interview techniques, direct observation of spaciousness, and documentation. The resource persons of this research are the corporate social responsibility of PT Angkasa Pura II (Persero), Neglasari villagers, and students of SMPN 2 Tangerang City. This study illustrates that PT Angkasa Pura II (Persero) enhances the company's image through the CSR program "Social Concern" by providing free medical assistance to Neglasari villagers and Tangerang City Junior High School 2 students carried out in Neglasari District as an effort of corporate responsibility to the community, has been stipulated in Law No. 40 of 2007 and ISO 26000 which contains three points and one of them is the company's responsibility to the social environment of the community. The results of this study conclude several things, namely: 1) PT Angkasa Pura II (Persero) running CSR in accordance with Law No. 40 of 2007 can prosper the community through social programs, 2) The implementation of CSR programs implemented is a social program by providing free medical assistance to residents villages and students that involve internal parties to establish good relations, 3) CSR program of PT Angkasa Pura II (Persero) providing free medical treatment social assistance receives positive values from the community, and students around the company.
\end{abstract}

Keywords: CSR, Social Care Program, Image 


\begin{abstract}
ABSTRAK
Penelitian ini untuk mengetahui program corporate social responsibility PT Angkasa Pura II (Persero) dalam meningkatkan citra perusahaan. Penelitian ini menggunakan metode deskriptif kualitatif, yaitu menggambarkan realitas yang dikaji. Teknik pengumpulan data menggunakan teknik wawancara mendalam, observasi terjun langsung kelapangan, dan dokumentasi. Narasumber penelitian ini adalah corporate social responsibility PT Angkasa Pura II (Persero), warga desa neglasari, dan pelajar SMPN 2 Kota Tangerang. Penelitian ini mengambarkan PT Angkasa Pura II (Persero) meningkatkan citra perusahaan melalui melalui program CSR "Kepedulian Sosial" dengan memberi bantuan pengobatan gratis kepada warga desa Neglasari dan pelajar SMPN 2 Kota Tangerang yang dilaksanakan di Kecamatan Neglasari upaya sebagai bentuk tanggung jawab perusahaan kepada masyarakat yang telah ditetapakan dalam UU No 40 Tahun 2007 dan Iso 26000 yang berisikan tiga poin dan salah satunya adalah tanggung jawab perusahaan kepada lingkungan sosial masyarakat. Hasil penelitian ini menyimpulkan beberapa hal, yaitu: 1) PT Angkasa Pura II (Persero) menjalankan CSR sesuai UU no 40 tahun 2007 dapat mensejahterakan masyarakat melalui program sosial, 2) Pelaksanaan program CSR yang diterapkan yaitu program sosial dengan memberikan bantuan pengobatan gratis kepada warga desa dan pelajar yang melibatkan pihak internal perusahaan agar terjalin hubungan baik, 3) Program CSR PT Angkasa Pura II (Persero) pemberian bantuan sosial pengobatan gratis mendapatkan nilai yang positif dari masyarakat, dan pelajar di sekitar lingkungan perusahaan.
\end{abstract}

Kata Kunci : CSR, Program Kepedulian Sosial, Citra

\section{PENDAHULUAN}

Di zaman era modern saat ini perusahaan sudah tidak lagi bergantung tanggung jawab pada keuntungan semata saja, melainkan bagaimana perusahaan mampu memberikan sumbangsi sosial kepada masyarakat sekitar. Karena perkembangan dan kemajuan perusahaan bukan berasal dari perusahaan itu sendiri tetapi karena adanya dukungan dan kepercayaan masyarakat terhadap suatu perusahaan. Seiring dengan perkembangan zaman yang semakin maju, perusahaan-perusahaan di Indonesia banyak yang bersaing mencari profit kepada tanggung jawab sosial perusahaan, termasuk di bidang sosial.

Corporate Social Responsibility bukan hanya sekedar pelaksanaan tanggung jawab saja, tetapi juga menjadi bentuk pembangunan yang berkelanjutan atau berjangka panjang. Menurut Muchlas Samani dan Hariyanto Program Kepedulian Sosial yaitu memperlakukan orang lain dengan sopan, bertindak santun, toleran terhadap perbedaan, mau 
berbagi, mampu bekerja sama, mau terlibat dalam kegiatan masyarakat, cinta damai dalam menghadapi persoalan. (Narwanti 2012:64-68). Wujud nyataa sebuah organisasi atau perusahaan dengan adanya perkembangan program-program perusahaan.

Perusahaan

melakukan

Corporate Social Responsibility sebagai bentuk tanggung jawab kesejahteraan masyarakat dan lingkungan sosial di sekitarnya. Di Indonesia sudah secara legal tertulis dalam Undang-Undang Republik Indonesia No. 40 Tahun 2007 tentang Perseroan Terbatas (PT) pasal 74, yaitu berkewajiban untuk berperan dalam dalam Tanggung Jawab Sosial Dan Lingkungan (TJSL). (A.B Susanto,2009:2).

Setiap perusahaan program Corporate Social Responsibility diyakini sebagai investasi yang menaikan kinerja jangka panjang perusahaan untuk membangun citra positif perusahaan di mata publik. Citra Perusahaan adalah suatu kesan atau gambaran dari sebuah perusahaan di mata masyarakat luas yang terbentuk berdasarkan pada pengetahuan dan pengalaman mereka pribadi. (Adona,2006:107)

Tanpa citra yang baik perusahaan tidak akan mendapatkan respon positif dari masyarakat. Karena citra perusahaan sangat penting bagi perusahaan untuk dapat bertahan dan berkembang sampai menuju puncak kesuksesan. Cara yang ditempuh untuk membangun citra perusahaan dan menjaga nama baik perusahaan, salah satunya melalui program Corporate Social Responsibility (CSR) yang telah dibuat oleh perusahaan. Citra suatu perusahaan akan dibuat sekuat mungkin dengan program Corporate Social Responsibility (CSR), sehingga perusahaan dapat mengetahui kepercayaan masayarakat.

Dengan adanya aktivitas program Corporate Social Responsibility (CSR), hubungan dengan publik dapat dibina dalam kaitan dengan kepercayaan publik, dan perusahaan akan mendapatkan timbal balik saling pengertian yang hamoris antar kedua belah pihak, yaitu perusahaan dan masyarakat sekitar atau publik. Saat hubungan yang baik dengan masyarakatnya terbina maka perusahaan akan mendapatkan citra yang positif.

Public relations sangat penting untuk bekerjasama melaksanakan program corporate social responbility perusahaan dalam membentuk citra positif. Harapannya dengan menggunakan public relations, perusahaan mampu membentuk citra positif berdasarkan pada kemampuan dan kelemahan internal ataupun eksternal, dan mengantisipasi perubahaan.

PT Angkasa Pura II (Persero) adalah salah satu Badan Usaha Milik Negara (BUMN) yang bergerak dalam bidang usaha pelayanan jasa kebandarudaraan dan pelayanan jasa 
terkait bandar udara di wilayah Indonesia Barat menjalankan berbagai program CSR yaitu Sosial, Lingkungan, Pendidikan, Ekonomi, dan Budaya. Dengan melakukan program-program yang dikelola oleh CSR diharapkan dapat membangun kualitas kepecayaan dan citra PT Angkasa Pura II (Persero) di mata publik, baik publik eksternal maupun internal.

Pada dasarnya tujuan utama dari program perusahaan tersebut sebagai salah satu menciptakan hubungan harmonis anatara organisasi atau perusahaan yang diwakili dengan stakeholder khalayak yang terkait. Hasil yang diharapkan adalah terciptanya citra positif, saling menghargai, saling timbul perhatian, toleransi antara kedua belah pihak. Program Kepedulian Sosial ini tentu saja menjadi sorotan publik karena bisa menjadi salah satu cara perusahaan unuk membantu perekonomian sosial masyarakat sekitar.

\section{Rumusan Masalah}

Berdasarkan latar belakang yang telah dibahas, maka permasalahan pada penelitian ini adalah "Program Corporate Social Responsibility PT Angkasa Pura II (Persero) Dalam Membangun Citra Perusahaan (Studi Deskriptif Kualitatif Pada Program Kepedulian Sosial 2019)

\section{A. Landasan Konseptual}

\section{Public Relations}

Definisi Public Relations yang telah dijelaskan oleh Cutlip, Center
Broom merujuk pada peran dan fungsi public relations dalam manjalankan dan mengatur komunikasi yang bertujuan untuk menciptakan dan menjaga hubungan baik yang saling menguntungkan dengan para publik organisasi.

Terciptanya hubungan baik antara organisasi dengan publik, dapat memudahkan suatu organisasi dalam mendapatkan image atau penilaian positif dari masyarakat, sehingga dengan demikian organisasi dapat dengan mudah mencapai tujuan bisnis mereka karena telah mendapatkan dukungan dari publik organisasi. (Rosady Ruslan,2001:1)

Tujuan dan Manfaat Public Relations

Empat hal yang prinsip dari tujuan Public Relations yakni:

1. Menciptakan citra yang baik.

2. Memelihara citra yang baik.

3. Meningkatkan citra yang baik.

4. Memperbaiki citra jika citra organisasi menurun atau rusak.

Frank Jefkins menyebutkan manfaat khusus public relations yang meliputi kegunaan public relations dalam pengelolaan atau pelaksanaan, antara lain : (Frank Jefkins,2004:33)

1. Manajemen Krisis

2. Penerbitan Desk-Top

3. Identitas Perusahaan

4. Hubungan Parlementer

5. Public Relations Financial

\section{Peran Public Relations}

Peran dari sebuah public relations (Wahidin Saputra \& Rulli Nasrullah,2011:50-52), yaitu: 
1. Sebagai komunikator

2. Membina relationship

3. Peranan backup management

4. Membentuk corporate image

\section{Strategi Public Relations}

Menurut Ahmad S. Adnanputra yang dikutip oleh Rosady Ruslan dalam bukunya Manajement Public Relations dan Komunikasi mengatakan bahwa arti strategi public relations adalah alternatif optimal yang dipilih untuk ditempuh guna mencapai tujuan public relations dalam kerangka atau rencana public relations (public relations plan). (Rosady Ruslan,2001:115)

Strategi public relations diarahkan kepada upaya-upaya menggarap persepsi para stakeholders untuk mencapai tujuan yang telah ditetapkan oleh organisasi atau perusahaan.

\section{Corporate Social Responsibility}

Dalam ISO 26000, CSR didefinisikan sebagai:

"Tanggung jawab suatu organisasi atas dampak dari putusan dan aktivitasnya terhadap masyarakat dan lingkungan, melalui perilaku yang transparan dan etis yang konsisten dengan pembangunan berkelanjutan dan kesejahteraan masyarakat; memperhatikan kepentingan stakeholder; sesuai hukum yang berlaku dan konsisten dengan norma-norma internasional; terintegrasi di seluruh aktivitas organisasi, dalam pengertian ini meliputi baik kegiatan, produk maupun jasa”. (Ujang Rusdianto,2013:7)

Tiga prinsip dasar yang dikemukakan oleh John Eklington (1997) "The Tripple Botton Line" yang dimuat dalam buku "Canibalts With Forks, The Tripple Botton Line Of Twentieth Century Business". Triple Bottom Lines yakni (Norhadi:57) :

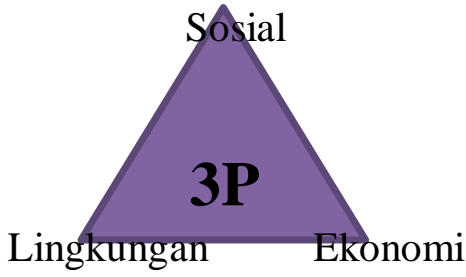

1. Profit, perusahaan tetap harus berorientasi untuk mencari keuntungan ekonomi yang memungkinkan untuk terus beroperasi dan berkembang.

2. People, perusahaan harus memiliki kepedulian terhadap kesejahteraan manusia.

3. Plannet, perusahaan peduli terhadap lingkungan hidup dan kelanjutan keragaman hayati.

Corporate Social Responsibility pada dasarnya adalah sebuah kebutuhan bagi korporat untuk dapat berinteraksi dengan komunitas lokal sebagai bentuk masyarakat secara keseluruhan. CSR idealnya adalah sebuah win-win solution dalam arti bahwa CSR tidak hanya menguntungkan perusahaan, tapi juga dapat mensejahterakan masyarakat dan lingkungan di mana perusahaan beroperasi.

Perkembangan CSR di Indonesia 
Perkembangan CSR di 30 Indonesia dimulai dari sejarah perkembangan Program Kemitraan Bina Lingkungan (PKBL). Pembinaan usaha kecil oleh BUMN telah dilaksanakan sejak terbitnya Peraturan Pemerintah Nomor 3 Tahun 1983 tentang tata cara pembinaan dan pengawasan Perusahaan Jawatan (Perjan), Perusahaan Umum (Perum) dan Perusahaan Perseroan (Persero).

Di Indonesia memiliki hukum tentang Tanggung Jawab Sosial dan Lingkungan dalam Undang-Undang Republik Indonesia nomor 40 tahun 2007 pasal 74 yaitu (Hendrik Budi Untung,2009:89) :

1. Perseroan yang menjalankan kegiatan usahanya dibidang dan/atau berkaitan dengan sumber daya alam wajib melaksanakan Tanggung Jawab Sosial dan Lingkungan.

2. Tanggung Jawab Sosial dan Lingkungan sebagaimana pada ayat (1) merupakan kewajiban Perseroan yang dianggarkan dan diperhitungkan sebagai biaya Perseroan yang pelaksanaannya dilakukan dengan memperhatikan kepautan dan kewajaran.

3. Perseroan yang tidak melaksanakan kewajiban sebagaimana dimaksud pada ayat (1) dikenai sanksi sesuai dengan ketentuan peraturan perundangundangan.
4. Ketentuan lebih lanjut mengenai Tanggung Jawab Sosial dan Lingkungan diatur dengan Peraturan Pemerintah.

\section{Tujuan dan Manfaat Pelaksanaan}

Tujuan Corporate Social Responsibility (CSR) dalam bisnis apapun yang diharapkan adalah keberlanjutan dan kesetabilan usaha, karena keberlanjutan akan mendatangkan keuntungan sebesarbesarnya bagi perusahaan.

Manfaat dari CSR itu sendiri terhadap pelaku bisnis sangat bervarisi, tergantung pada sifat (natural) perusahaan bersangkutan dan sulit diukur secara kuantitatif. Meskipun demikian, ada sejumlah besar literatur yang menunjukkan adanya korelasi antara kinerja sosial/lingkungan dengan kinerja finansial dari perusahaan. (Ujang Rusdianto,2013:12).

Terdapat manfaat yang didapatkan dari pelaksanaan tanggunggjawab sosial perusahaan, baik bagi perusahaan sendiri, bagi masyarakat, pemerintah dan pemangku kepentingan lainnya, diantaranya :

1. Bagi perusahaan.

Terdapat empat manfaat yang diperoleh perusahaan dengan mengimplementasikan CSR.

Pertama, keberadaan perusahaan dapat tumbuh dan berkelanjutan dan perusahaan mendapatkan citra yang positif dari masyarakat luas. Kedua, perusahaan lebih mudah memperoleh akses terhadap modal (capital). 
Ketiga, perusahaan dapat mempertahankan sumber daya manusia (human resources) yang berkualitas. Keempat, perusahaan dapat meningkatkan pengambilan keputusan pada hal-hal yang kritis (critical decision making) dan mempermudah pengelolaan manajemen risiko (risk management).

2. Bagi masyarakat.

Praktik CSR yang baik akan meningkatkan nilaitambah adanya perusahaan di suatu daerah karena akan menyerap tenaga kerja, meningkatkan kualitas sosial di daerah tersebut. Pekerja lokal yang diserap akan mendapatkan perlindungan akan hak-haknya sebagai pekerja. Jika terdapat masyarakat adat atau masyarakat lokal, praktek CSR akan mengharagai keberadaan tradisi dan budaya lokal tersebut.

3. Bagi lingkungan.

Praktik CSR akan mencegah eksploitasi berlebihan atas sumber daya alam, menjaga kualitas lingkungan dengan menekan tingkat polusi dan justru perusahaan terlibat mempengaruhi lingkungannnya.

4. Bagi Negara.

Praktik CSR yang baik akan mencegah apa yang disebut "corporate misconduct" atau malpraktik bisnis seperti penyuapan pada aparat negara atau aparat hukum yang memicu tingginya korupsi. Selain itu, negara akan menikmati pendapatan dari pajak yang wajar (yang tidak digelapkan) oleh perusahaan.

\section{Ruang Lingkup dan Model} Corporate Social Responsibility

Menurut Carroll (2003:36-39), ruang lingkup Corporate Social Responsibility terbagi atas:

a. Tanggung Jawab Ekonomi (Economic Responsibilities)

b. Tanggung Jawab Hukum (Legal Responsibilities)

c. Tanggung Jawab Etika (Ethical Responsibilities)

d. Tanggung Jawab Sukarela dan Diskresioner

e. Tanggung Jawab Perusahaan

f. Tanggung Jawab Sosial Perusahaan.

\section{Jenis-Jenis CSR}

Kotler dan Lee (dalam Putra,2012) mengidentifikasi enam pilihan program bagi perusahaan untuk melakukan inisiatif dan aktivitas sebagai wujud komitmen dari tanggung jawab sosial perusahaan. Keenam inisiatif sosial tersebut antara lain:

1. Promosi Kegiatan Sosial (Cause Promotions)

2. Pemasaran Terkait Kegiatan Sosial (Cause Related Marketing)

3. Pemasaran Kemasyarakatan Korporat (Corporate Societal Marketing)

4. Kegiatan Filatropi Perusahaan (Corporate Philantrophy)

5. Pekerja Sosial Kemasyarakatan Secara Sukarela (Community Volunteering) 
6. Praktik Bisnis yang Memiliki Tanggung Jawab Sosial (Socially Responsible Business Practice)

\section{Proses Pelaksanaan CSR}

Berikut ini adalah langkahlangkah bagaimana pelaksanaan program yang telah dilakukan. (Kotler,2005:25) :

a. Unit pelaksana dan pengelola.

b. Dana Bantuan sumber dana bantuan.

c. Leadership (kepemimpinan).

d. Transparansi dan Akuntabilitas.

e. Monitoring dan Evaluasi.

\section{Citra}

Menurut Frank Jefkins citra dapat dikatakan sebagai presepsi masyarakat dari adanya pengalaman, kepercayaan, perasaan, dan pengetahuan masyarakat itu sendiri terhadap perusahaan, sehingga aspek fasilitas yang dimiliki perusahaan, dan layanan yang disampaikan karyawan kepada konsumen dapat mempengaruhi persepsi konsumen terhadap citra. (Frank Jefkins,2003:39)

Menurut Frank Jefkins, dalam buku Public Relations yang dikutip oleh Soemirat, membagi citra dalam beberapa jenis, antara lain:

1. Mirror image (Citra Bayangan)

Citra bayangan merupakan kesan yang dianut oleh anggota mengenai pandangan luar terhadap organisasinya (Frank Jefkins, 2003:20). Citra ini cenderung bersifat positif.

2. Current Image (Citra Yang Berlaku)
Citra current merupakan pandangan yang dianut oleh pihakpihak luar mengenai suatu organisasi. Citra yang berlaku tidak selamanya sesuai dengan kenyataan karena semata-mata terbentuk dari pengalaman atau pemahaman orangorang luar yang bersangkutan yang biasanya tidak memadai. Citra ini biasanya cenderung ke bentuk negatif.

3. Wish Image (Citra Harapan)

Citra harapan adalah suatu citra yang diinginkan oleh pihak manajemen (Frank Jefkins,2003:21). Citra harapan dirumuskan dan diperjuangkan untuk menyambut sesuatu hal yang relatif baru, yaitu ketika khalayak belum memiliki informasi yang memadai.

\section{Corporate Image (Citra}

Perusahaan)

Citra perusahaan merupakan citra dari suatu organisasi secara keseluruhan, jadi tidak hanya citra atas produk dan pelayanannya saja (Frank Jefkins,2003:22).

\section{Peran Citra}

Menurut Shirley Harrison (2004:71) ada empat elemen untuk mendapatkan suatu informasi yang lengkap, yaitu sebagai berikut :

1. Personality,

2. Reputation,

3. Value,

4. Corporate Identity,

5. Proses pembentukan citra.

\section{Unsur Citra}

1. Citra Negatif 
Citra negatif adalah kebalikan dari citra positif. Citra negatif adalah sebuah kesan yang buruk, imbas dari hal negatif yang telah dilakukan organisasi atau instansi yang ditunjukkan publik kepada organisasi maupun instansi tersebut, bisa berupa pesan langsung atau tidak langsung (M. Linggar, 2001: 69).

\section{Citra Positif}

Citra humas yang ideal adalah sebuah kesan baik yang ditunjukkan publik kepada organisasi, perusahaan, instansi maupun individu lainnya. Kesan yang benar itu sepenuhnya berdasarkan pengalaman, pengetahuan, serta pemahaman atas kenyataan yang sesungguhnya. Citra positif sendiri berakar dari kepercayaan publik terhadap apa yang telah skita lakukan.

\section{B. Metodologi Penelitian}

\section{Paradigma Penelitian}

Peneliti ini menggunakan paradigma kontruktivisme, karena penelitian ini bertujuan untuk untuk memahami dan mendeskripsikan bagaimana CSR dalam mengelola dunia sosial mereka, dalam hal ini adalah proses pelaksanaan program CSR yang dijalankan oleh PT Angkasa Pura II (Persero) dalam memenuhi kebutuhan masyarakat sekitar agar mendapat nilai yang positif.

\section{Metode Penelitian}

Peneliti menggunakan jenis metode kualitatif karena pada penelitian kualitatif, peneliti memasuki situasi sosial tertentu, melakukan observasi dan wawancara kepada orang-orang yang dipandang tahu tentang situasi sosial tersebut, dan penelitian ini berusaha mencari gambaran satu kelompok manusia untuk mencapai tujuan kelompok tersebut, sehingga dapat terungkap secara jelas dan akurat.

\section{Tradisi Penelitian}

Penelitian ini menggunakan Deskriptif Kualitatif. Penelitian deskriptif kualitatif berusaha menggambarkan suatu gejala sosial. Peneliti beranggapan bahwa tradisi penelitian deskriptif kualitatif sesuai dengan penelitian yang dilaksanakan oleh peneliti, karena penelitian ini lebih fokus ke arah pembahasan program CSR dalam bidang kepedulian yang dijalankan oleh PT Angkasa Pura II (Persero) agar dapat membangun citra perusahaan yang positif. Dengan menggunakan penelitian deskriftif kualitatif peneliti dapat menggambarkan apa yang terjadi di perusahaan tersebut dan kegiatan-kegiatan apa saja yang dilakukan oleh perusahaan sehingga dapat menghasilkan citra positif.

\section{Teknik Pengumpulan Data}

Berikut ini akan dijelaskan teknik-teknik pengumpulan data yang digunakan oleh peneliti sebagai berikut:

1. Observasi yang dilakukan peneliti dengan survey, terjun langsung kelapangan atau mengikuti kegiatan program CSR dan melakukan pencatatan guna 
untuk menyempurnakan penelitian agar mencapai hasil yang maksimal.

2. Wawancara yang digunakan dalam penelitian dengan mengajukan pertanyaanpertanyaan terstruktur karena peneliti menggunakan pedoman wawancara yang disusun secara sistematis dan lengkap untuk mengumpulkan data yang dicari. Wawancara digunakan untuk memperkuat dan memperjelas data yang diperoleh yaitu data tentang profil dan kegiatan CSR PT Angkasa Pura II (Persero).

3. Dokumentasi, peneliti mencermati dan mempelajari berbagai buku-buku teks, jurnal, catatan selama perkuliahan untuk membandingkan teori-teori yang sudah ada dengan data yang akan diperoleh. Peneliti juga memperoleh informasi melalui media internet, khususnya pada website. Dokumentasi atau studi kepustakaan dokumentasi yaitu memperoleh data dengan cara mencatat dan mengumpulkan data dari PT Angkasa Pura II (Persero), seperti sejarah perusahaan, bentuk program kepedulian sosial, dan peneliti mendokumentasikannya melalui foto.

\section{Teknik Analisis Data}

Model analisis interaktif terdiri dari tiga komponen analisis, yaitu pengumpulan data, reduksi data (data reduction) penyajian data (data display), dan penarikan kesimpulan (conclution drawing and verifying).

1) Pengumpulan Data

Dalam penelitian ini peneliti mengumpulkan data yang berupa foto, dokumentasi, dan wawancara yang peneliti dapatkan dari hasil observasi di PT Angkasa Pura II (Persero).

2) Reduksi Data (Data Reduction)

Setelah semua hasil data yang berupa foto, dokumentasi, dan wawancara diperoleh, selanjutnya peneliti melakukan proses pemilihan yang didapat dari lapangan selama proses pengamatan di PT Angkasa Pura II (Persero).

3) Penyajian Data (Data Display)

Langkah selanjutnya setelah proses reduksi data akan diproleh hasil data kasar yang kemudian akan disusun oleh peneliti sehingga data dari proses pengamatan. Bisa tersusun dengan sistematis sehingga memudahkan peneliti melakukan penarikan kesimpulan.
4) Penarikan
Kesimpulan

(Conclution Drawing And Verifying)

Langkah terakhir setelah penyajian data adalah penarikan kesimpulan oleh peneliti. Setiap kesimpulan yang dibuat oleh peneliti semata-mata didasarkan pada data yang dikumpulkan dan diolah. Hasil penelitian tergantung pada kemampuan peneliti untuk menafsirkan secara logis data yang telah disusun secara sistematis 
menjadi ikatan pengertian sebabakibat obyek penelitian.

\section{Pembahasan}

Corporate Social Responsibility menurut Kotler dan Lee (dalam Ismail Solihin,2011) mendefinisikan CSR adalah komitmen perusahaan untuk meningkatkan kesejahteraan komunitas melalui praktik bisnis yang baik, dan mengkontribusikan sebagian sumberdaya perusahaan.

Jadi peneliti dapat menyimpulkan bahwa Corporate Social Responsibility adalah suatu konsep atau tindakan yang dilakukan oleh perusahaan sebagai rasa tanggung jawab perusahaan terhadap sosial maupun lingkungan sekitar dimana perusahaan itu berada, seperti melakukan suatu kegiatan untuk warga yang tidak mampu di daerah tersebut, yang bersifat sosial dan berguna untuk masyarakat banyak, khususnya masyarakat yang berada di sekitar perusahaan tersebut berada agar dapat meningkatkan kesejahteraan masyarakat sekitar dan menjaga hubungan baik dengan memberikan bantuan sosial.

Hubungan baik yang terbentuk dari CSR program sosial yang diberikan perusahaan kepada masyarakat dan pelajar berdampak pada penilaian positif dari masyarakat sekitar dan tentu saja meningkatkan kesejahteraan masyarakat dan meningkatkan citra positif perusahaan. Citra yang baik dari suatu organisasi akan mempunyai dampak yang menguntungkan, sedangkan citra yang negatif akan merugikan suatu perusahaan. Citra yang baik berarti masyarakatnya mempunyai kesan positif terhadap suatu organisasi.

Dalam menjalankan kegiatan CSR, PT Angkasa Pura II (Persero) melakukan 3 jenis program dalam pelaksanaan CSR kegiatan sosial, yaitu:

\section{Corporate Social Marketing}

Pada pelaksanaan program CSR ini, PT Angkasa Pura II (Persero) bersosialisasi dan memberikan bantuan sosial dengan berkontribusi langsung kepada masyarakat agar dapat meningkatkan kesejahteraan dengan memberikan sumbangan sosial. Perusahaan berharap agar masyarakat dapat menerima, menjaga, dan memanfaatkan pemberian dari program CSR dengan baik. Sehingga timbul rasa memiliki program dan hasil program pada masyarakat agar masyarakat dapat ikut andil dalam menjaga.

\section{Cause-Related Marketing}

Pada aktivitas ini dibentuknya sebuah komitmen perusahaan terhadap program tanggung jawab sosial yang telah dibuat. Program yang telah dibuat selayaknya dilaksanakan secara berkelanjutan dan konsisten. Serta bagaimana perusahaan mengakampanyekan dengan berbagai media mengenai program yang telah ada. Program CSR dapat dikatakan berhasil jika mendapat dukungan dari internal perusahaan. 
Internal PT Angkasa Pura II (Persero) sadar akan pentingnya melaksanakan program CSR yang melibatkan tim iternal untuk membantu masyarakat yang ada di lingkungan sekitar perusahan dengan menerapkan kegiatan CSR kepedulian sosial dengan memberikan bantuan atau sumbangan pengobatan gartis di pemukiman warga, dan di sekolah.

Pada pelaksanaan program ini tim CSR dibantu dengan tim PR PT Angkasa Pura II (Persero) dalam menjalankan kegiatan CSR, tim CSR yang bersosialisasi langsung dengan masyarakat dan tim PR yang meliput atau mendokumentasikan kegiatan CSR.

\section{Corporate Philanthropy}

Pada pelaksanaan ini PT Angkasa Pura II (Persero) membuat serta melaksanakan sebuah program untuk tujuan sosial dan memenuhi tanggung jawab sosial perusahaan terhadap masyarakat internal maupun eksternal perusahaan.

PT Angkasa Pura II (Persero) dalam membentuk citra positif melakukan program-program yang bermanfaat. Citra yang di terima PT Angkasa Pura II (Persero), yaitu:

1) Citra bayangan atau mirror image yaitu pandangan publik terhadap perusahaan. PT Angkasa Pura II (Persero) sudah banyak dikenal publik sebagai perusahaan BUMN yang melayani jasa penerbangan yang giat menjalankan tugas program
CSR guna membantu masyarakat sekitar perusahaan, namun masih ada beberapa yang bernilai buruk terhadap perusahaan ataupun kepada internalnya untuk menangapi penilaian buruk tersebut internal PT Angkasa Pura II (Persero) bertemu langsung dengan masyarakat dengan membuat sosialisasi bersama masyarakat untuk memberikan klarifikasi ataupun informasi yang lebih jelas.

2) Citra yang berlaku atau current image suatu citra atau pandangan eksteral mengenai pihak internal. Sama halnya dengan citra bayangan, masyarakat/publik kurang mengatahui informasi mengenai PT Angkasa Pura II (Persero) yang kurang jelas, cara PT Angkasa Pura II (Persero) untuk meyakinkan masyarakat dengan mengadakan sosialisasi bersama-sama.

3) Citra yang diharapkan atau wish image yaitu suatu citra yang diinginkan atau menjadi tujuan oleh pihak manajemen atau suatu organisasi. Salah satu cara PT Angkasa Pura II (Persero) untuk meningkatkan citra dibutuhkan citra harapan dengan melaksanakan sosialisasi bersama dan menjalankan kegiatan program CSR untuk membantu masyarakat sekitar dan menarik perhatian masyarakat diberikan sumbangan atau bantuan pengoatan gratis 
dan sosialisasi. Dengan programprogram CSR yang dijalankan PT Angkasa Pura II (Persero) masyarakat akan melihat bawha PT Angkasa Pura II (Persero) memang sangat penting untuk perduli dengan lingkungan sekitar perusahaan. Jadi masyarakat memandang PT Angkasa Pura II (Persero) dari sisi positif disbanding sisi negatifnya.

4) Citra perusahaan atau corporate image yaitu citra dari PT Angkasa Pura II (Persero) secara keseluruhan, bukan sekedar citra atas jasa pelayanan udara saja. Citra perusahaan ini terbentuk dari banyak hal, seperti sejarah perusahaan yang bagus, hubungan internal maupun eksternal yang baik, reputasi sebagai pencipta lapangan kerja, dan tanggung jawab sosial. PT Angkasa Pura II (Persero) memubutuhkan citra yang baik sehingga dapat menarik perhatian masyarakat dengan memberikan bantuan sosial. PT Angkasa Pura II (Persero) melakukan peningkatkan citra dengan cara tim CSR mendekatkan ke masyarakat dan dibantu tim PR untuk mendokumentasikan, memberikan sosialisasi yang baik dan jelas ke masyarakat sekitar perusahaan, membuat kegiatan program CSR yang sudah di tetapkan di undang-undang.
Jadi tujuan dari pelaksanaan program CSR adalah untuk meningkatkan citra positif perusahaan yang perduli terhadap masalah sosial atau yang lainnya. Program CSR yang dilakukan PT Angkasa Pura II (Persero) memberikan bantuan pengobatan kesehatan gratis guna untuk menjalin hubungan baik dengan masyarakat agar terciptanya keharmonisan sehingga meningkatkan citra perusahaan dari manfaat yang dirasakan bersama.

\section{Penutup}

\section{Kesimpulan}

1. PT Angkasa Pura II (Persero) dalam meningkatkan kesejahteraan masyarakat melalui program CSR yang diberikan kepada warga desa neglasari dan kepada pelajar SMPN 2 Kota Tangerang berupa bantuan sosial pengobatan gratis, pemberian kacamata gratis, dan pemberian kursi roda gratis untuk membantu, dan meningkatkan kesejahteraan masyarakat yang bermanfaat.

2. Pelaksanaan program CSR PT Angkasa Pura II (Persero) yang dijalankan berupa bantuan sosial kepada warga desa Neglasari dan pelajar SMPN 2 Kota Tangerang sudah sesuai dengan penerapan konsep CSR, yakni corporate social marketing, cause related marketing, dan corporate philanthropy. 
3. Dengan program yang telah dijalankan berupa bantuan sosial kesehatan gratis dapat memberikan feedback dampak citra positif kepada perusahaan yang ditunjukan oleh antusias warga dan pelajar sesesuai dengan hasil wawancara.

\section{Saran}

1. Diharapkan kegiatan peduli sosial ini bisa lebih berkembang agar masyarakat terus merasakan kesejahteraan sosial.

2. Pelaksanaan program sosial PT Angkasa Pura II (Persero) selain memberikan bantuan sosial pengobatan gratis kepada masyarakat sekitar perusahaan, diharapkan dapat memberikan manfaat dan tetap terus menjaga hubungan baik yang sudah terbina dengan masyarakat sekitar, dan terus bekerjasama dengan baik dengan tim internal.

3. Diharapkan PT Angkasa Pura II (Persero) selama ini dapat terus mempertahankan bahkan meningkatkan citra perusahaan melaui kegiatan programprogram yang dijalankan oleh CSR PT Angkasa Pura II (Persero).

\section{DAFTAR PUSTAKA}

Ardianto, Elvinora, Soleh Soemirat. 2011. Dasar-Dasar Public Relations. Bandung: Remaja Rosdakarya"
Arikunto, Suharsimi. 2013. Prosedur

Penelitian Suatu Pendekatan

Praktik. Jakarta : Rineka Cipta

Bodgan, Biklen. 2001. Pengantar Studi Penelitian. Bandung : PT. ALFABETA

Bungin, Burhan. 2010. Metode Penelitian Kualitatif. Jakarta : Rajawali Pers

Dedy N. Hidayat. 2003. Paradigma dan Metodologi Penelitian Soal Empirik Klasik. Jakarta : Departemen Ilmu Komunikasi FISIP Universitas Indonesia

Denzin, Norman K \& Yvonna S. Lincoln. 2009. Metode Penelitian Kualitatif. Jogjakarta : Pustaka Pelajar

Hamidi. 2004. Metode Penelitian Kualitatif : Aplikasi Praktis Pembuatan Proposal dan Laporan Penelitian. Malang Herdiansyah, Haris. 2010. Metode Penelitian Kualitatif. Jakarta : Salemba Humanika

Jefkins, Frank. 2003. Public Relations Edisi Kelima. Jakarta: PT Gelora Aksara Pratama, penerbit Erlangga.

Kotler, Philip and Nancy Lee. 2005. Corporate Social Responsibility. Amerika : John Wiley\&Sons, Inc

M. Iqbal Hasan. 2002. Pokok-Pokok Materi Metodologi Penelitian dan Aplikasinya. Jakarta : Bumi Askara 
Moleong, Lexy. J. 2010. Metode Penelitian Kualitatif. Bandung : Remaja Rosdakarya

Rusdianto, Ujang. 2013. CSR Communication

$a$ Framework for PR Practitionsers. Yogyakarta: Graha Ilmu.

Ruslan, Rosady. 2003. Metode Penelitian Public Relations dan Komunikasi, Jakarta : PT. Raja Grafiado Persada.

Ruslan, Rosady. 2010. Manajemen Humas dan Manajemen Komunikasi. Jakarta PT. Raja Grafindo Persada

Sholihin, Ismail. 2011. Corporate Social Responsibility from
Charity to Sustainability. Jakarta: Salemba Empat. Subagyo, P. Joko. 1997. Metode Penelitian : Dalam Teori dan Praktek. Jakarta : Rineka Cipta

Sugiyono. 2015. Metode Penelitian Pendidikan Pendekatan Kuantitatif, Kualitatif, dan R\&D. Bandung: PT. ALFABETA

Sugiyono. 2005. Metode Penelitian Bisnis. Bandung: PT. ALFABETA

Sutopo. 2006. Metodologi Penelitian Kualitatif. Surakarta

Website/Internet :

https:///www.angkasapura2.co.id https:///bangzul.com/dasar-hukum-

csr/amp/ 